\title{
The Evolution of National Spatial Data Infrastructure in Pakistan - Implementation Challenges and the Way Forward*
}

\author{
Asmat Ali ${ }^{1}$, Muhammad Imran² \\ ${ }^{1}$ Institute of Geoinformation \& Earth Observation, PMAS-ARID Agriculture \\ University, Rawalpindi, Pakistan.asmatali@yahoo.com \\ ${ }^{2}$ Institute of Geoinformation \& Earth Observation, PMAS-ARID Agriculture \\ University, Rawalpindi, Pakistan. imran.igeo@uaar.edu.pk
}

\begin{abstract}
Geospatial data are produced by several organizations located at various places, and that is clearly a distributed environment. Many technical and institutional issues need to be resolved to share data in such an environment and to eventually enable regional development. For this matter, many countries implement Spatial Data Infrastructures (SDIs) for the last 40 years. Since 2010, also Pakistan is striving to implement an SDI at the national level (NSDI). However, so far, the promised benefits have not yet been achieved. This study explores the evolution of the NSDI in Pakistan from 2010 till 2020 to reveal what kind of challenges the country is facing. Given the importance of stakeholders' support for the implementation of SDIs, we conducted a stakeholder analysis and a dedicated survey. We adopted the power-interest grid method to classify stakeholders' interests based on their authority to influence the NSDI development. Among other, the results show that stakeholders' low participation due to insufficient technological, financial, and human resources impedes NSDI implementation efforts in the country.
\end{abstract}

Keywords: Spatial data infrastructure, NSDI, Pakistan, stakeholder analysis, power-interest grid method, SWOT

\footnotetext{
*This work is licensed under the Creative Commons Attribution-Non commercial Works 3.0 License. To view a copy of this license, visit http://creativecommons.org/licenses/by-nc-nd/3.0/ or send a letter to Creative Commons, 543 Howard Street, $5^{\text {th }}$ Floor, San Francisco, California, 94105, USA.

DOI: 10.2902/1725-0463.15.art5
} 


\section{INTRODUCTION}

Geospatial data are produced by several organizations located at various places, and that is clearly a distributed environment. In this environment, technical and institutional issues need to be resolved so that sharing of the data can be enabled and costly process of collecting the datasets again are avoided. To address these issues, Spatial Data Infrastructures (SDIs) are being developed at various geographic scales in many countries of the world for the last 40 years (Bucher et al., 2020). More than half of the countries in the world are developing a National Spatial Data Infrastructure (NSDI) (Masser, 2005a). An NSDI is a framework of technology, standards, policy, and collaboration of different institutions to ensure national access, exchange, and utilization of spatial data (Georgiadou et al., 2005; Masser, 2005b; Nikolina Mijić \& Šestić, 2018; Williamson et al., 2003). There can be several applications of NSDI having positive impacts on the social, environmental, and economic aspects of a country as find (Almirall \& Bergadà, 2008; Campagna \& Craglia, 2012; Crompvoets, de Bree, et al., 2007; Masser, 2005a, 2019; Richter et al., 2010).

Understanding needs and rationales for SDI development cannot be exactly the same for developed and developing countries though it may have some commonalities (Asmat, 2009), such as for improving national planning and supporting socio-economic developments (Ayanlade et al., 2008; Bucher et al., 2020; Čada \& Janečka, 2016; Fernández \& Crompvoets, 2008; Panagiotis \& Maria, 2013). Masser (2005b) while arguing about SDI developments finds that "SDIs are dynamic innovations as they are likely to be re-invented during the diffusion process to meet the needs of different national circumstances" (p.21). De Man, (2006) also supports above arguments, "SDIs and other kinds of information infrastructure alike are different at different spatial (or geographical) levels because of differentiated social contexts".

Since the early 1990s, initiatives to develop spatial data infrastructures have been carried out in many countries around the world (Richter et al., 2010) and NSDIs have evolved over different generations. According to (Masser, 1999), the first generation was typically led by national mapping agencies to promote economic development, stimulate better government, and foster environmental sustainability. Accordingly, the priority of first-generation SDls was better reuse of existing products or the design of specific new products from multiple sources (Masser, 1999). In the second generation of SDIs data sharing and utilization is facilitated by geoportals (Maguire \& Longley, 2005). Geoportals allow citizens to visualize various information products through the World Wide Web, and they allow to discover and access data from other providers (Bucher et al., 2020). 
The rapid advancements in spatial knowledge leading to more innovative technology and the Internet have changed the landscape of NSDIs. Bucher and others also find that, "a growing amount of spatial data stemming from different technologies (data delivered by the administration under the Public Sector Information directive, satellites, airborne sensors, in situ sensors, social networks, etc.), and it is more and more complex for a user to discover data, compare them, and select the best ones" (Bucher et al., 2020). Therefore, the future SDI developments are expected to be influenced by the growing number of social networks, mobile devices, computing and crowdsourcing services to integrate data of various types as envisions (Harvey et al., 2012). In order to make use of these technologies, NSDIs developments have to cater for not only technical aspects but also agreement with common policies, standards, and institutional frameworks (Crompvoets, Leuven, et al., 2007; Diaz et al., 2012).

This article explores the evolution of the NSDI in Pakistan from 2010 until 2020 to explore what kind of challenges the country is facing.

\section{THE EVOLUTION OF NSDI IN PAKISTAN}

\subsection{Planting the seeds of NSDI: A cultivation approach}

Pakistan is not an early adopter of the first-generation (N)SDI in terms of its initiative for implementing SDI at the national level. The reasons behind this reactive approach by policy makers were related to the relatively underestimated socio-economic value of Geographic Information (Gl) in the past (Asmat, 2008). There had been a lack of political support to regard Gl as a national asset (Masser, 2005a). Consequently, the establishment of appropriate policy, institutional and legal arrangements to deal with matters of GI was not seen as a priority.

However, in 2010, the Government of Pakistan through the Survey of Pakistan (SoP) started organizational efforts for the development of the country's NSDI (de Vries \& Asmat, 2016). The primary objective of the NSDI development was to eliminate duplication of efforts in the collection of geospatial data by setting up a data-sharing platform at the national level. The secondary objective was to regulate the geospatial industry and to coordinate geospatial information production. In 2010 the SoP sent a proposal for the development of the NSDI to the concerned ministry for approval. In 2012 the SoP presented the idea for the NSDI to the sectary of the ministry. And in 2013 the ministry approved the development of the NSDI for Pakistan.

To promote inter-agency coordination in the context of NSDI implementation in the country, more than 20 public and private sector organizations were visited by a delegation of SoP that was headed by the then Surveyor General of Pakistan (Ali \& Ahmad, 2013). Parallel to these developments, the SoP carried out a feasibility 
study for NSDI development (de Vries \& Asmat, 2016). Still, instead of taking fully coordinated actions to implement the NSDI, the developments remained fragmented. It took almost four years (March 2010 to May 2014) to arrive at a joint understanding between the major stakeholders that are producing fundamental and thematic geospatial information that sharing of their datasets through an NSDI will not result in losing control of their data holdings and that the data assets will remain in their custody. During these four years, some reach publications (Asmat \& Munir, 2014; Asmat \& Munir, 2012; Asmat, 2010a, 2010b) were shared with national geospatial communities underlining the benefits of sharing geospatial data through the implementation of NSDI in the local context of the country. The publications helped to create awareness among the stakeholders of geospatial data in Pakistan.

In May 2014, the legal framework for the development of NSDI in Pakistan, the Surveying and Mapping Act (GOP, 2014), passed the National Assembly of Pakistan. The clause 15 of the Act titled as management of geospatial data states that the "Survey of Pakistan shall establish and maintain National Spatial Data infrastructure (NSDI) with the support of key stakeholders to ensure consistent mechanism of maintenance, dissemination and sharing geospatial data among all users by reducing duplication in collection and maintenance of aforesaid data and to enhance and improve objective decision making". The Surveying and Mapping Act gave the SoP the mandate to establish and maintain the NSDI with the support of key stakeholders but no mechanism for collaborating with the stakeholders were yet to be put in place. The retirement of two Surveyor Generals of Pakistan within five years caused significant delay in pursuing this initiative.

In order to transform the fragmented efforts by SoP, SUPARCO, PARC and PBS into a shared activity, on May 15, 2020 a national coordination committee has been formed on the directions of the concerned ministry. The committee is responsible for making collaborative efforts for the development of the NSDI. It includes one representative from each government department, private sector organizations and academic institutions.

The trajectory of NSDI in Pakistan is summarized in Table 1. This again illustrates how the developments formed into a collaborative initiative. This coordinated effort for the implementation of the NSDI for Pakistan is the right direction, also according to SDI literature (Fernández \& Crompvoets, 2008; Yola Georgiadou et al., 2005; Masser, 2005a, 2019; Rajabifard, A., Feeney, M. E. F., \& Williamson, 2003; Richter et al., 2010). 
Table 1: Trajectory of NSDI development in Pakistan

\begin{tabular}{|c|c|c|c|c|}
\hline Period & $\begin{array}{l}\text { NSDI related } \\
\text { activities }\end{array}$ & Data Policy & $\begin{array}{l}\text { Technological } \\
\text { Changes }\end{array}$ & Users \\
\hline $2009-10$ & $\begin{array}{l}\text { Organizational efforts } \\
\text { by SoP }\end{array}$ & $\begin{array}{l}\text { Pay for digital } \\
\text { geospatial } \\
\text { data }\end{array}$ & $\begin{array}{l}\text { Desktop GIS, } \\
\text { Server GIS and } \\
\text { Geodatabase }\end{array}$ & $\begin{array}{l}\text { Federal and } \\
\text { provincial } \\
\text { government } \\
\text { department, } \\
\text { NGOs and } \\
\text { academia }\end{array}$ \\
\hline 2011-12 & $\begin{array}{l}\text { Organizational and } \\
\text { isolated efforts by } \\
\text { SoP \& SUPARCO }\end{array}$ & $\begin{array}{l}\text { Pay for digital } \\
\text { geospatial } \\
\text { data }\end{array}$ & $\begin{array}{l}\text { Web mapping } \\
\text { \& Geoportal } \\
\text { provision } \\
\text { through Local } \\
\text { Area Network } \\
\text { (LAN) }\end{array}$ & $\begin{array}{l}\text { Federal and } \\
\text { provincial } \\
\text { government } \\
\text { departments, } \\
\text { NGOs and } \\
\text { academia }\end{array}$ \\
\hline 2013-14 & $\begin{array}{l}\text { Organizational and } \\
\text { isolated efforts by } \\
\text { SoP, SUPARCO, } \\
\text { Pakistan agricultural } \\
\text { research council } \\
\text { (PARC) and Pakistan } \\
\text { bureau of statistics } \\
\text { (PBS) }\end{array}$ & $\begin{array}{l}\text { Pay for digital } \\
\text { geospatial } \\
\text { data }\end{array}$ & $\begin{array}{l}\text { Geoportal, } \\
\text { participatory } \\
\text { mapping, and } \\
\text { mobile } \\
\text { applications }\end{array}$ & $\begin{array}{l}\text { Federal and } \\
\text { provincial } \\
\text { government } \\
\text { departments, } \\
\text { private } \\
\text { companies, } \\
\text { NGOs and } \\
\text { academia }\end{array}$ \\
\hline $\begin{array}{l}\text { 2015- } \\
\text { Present }\end{array}$ & $\begin{array}{l}\text { Institutional and } \\
\text { collaborative efforts } \\
\text { started. A national } \\
\text { coordination } \\
\text { committee formed for } \\
\text { accelerating } \\
\text { implementation of } \\
\text { the NSDI. }\end{array}$ & $\begin{array}{l}\text { Small scale } \\
\text { base-maps } \\
\text { freely } \\
\text { available for } \\
\text { download }\end{array}$ & $\begin{array}{l}\text { Geoportal, } \\
\text { participatory } \\
\text { mapping, and } \\
\text { mobile } \\
\text { applications }\end{array}$ & $\begin{array}{l}\text { Federal and } \\
\text { provincial } \\
\text { government } \\
\text { departments, } \\
\text { private } \\
\text { companies, } \\
\text { NGOs and } \\
\text { academia }\end{array}$ \\
\hline
\end{tabular}

\subsection{Problem Identification}

To identify the remaining challenges in implementing the NSDI for Pakistan, various organizations were visited between 2014 and 2020, and a meeting of the major stakeholders was arranged at the SoP on 3rd March 2020. All these meetings ware used to interact and conduct semi-structured interviews of representatives of major stakeholder organizations. The purposive sampling technique was used in order to choose the representatives based on two criteria. First, we identified interviewees with experience in geospatial disciplines. Second, we selected those interviewees who were familiar with the NSDI and with geospatial services. Our experiences made through publications, presentations and discussions about the NSDI initiative over the last decade proved to be very helpful in finding and approaching suitable candidates. 
A total of 20 representatives of the stakeholders were identified by us for interview: 10 working in public sector organizations, 7 for private sector organizations, and 3 from academic institutions. The selected interviewees have been performing different roles in their organizations, including: an SDI coordinator at the federal ministry, a GIS manager at the provincial government, a director of the GIS software provider, an information technology (IT) expert at a web mapping company, and an assistant professor at a university.

Before starting with the first part of the interview, profile information i.e. resumes were collected. All the interviewees claimed to have knowledge and experience of GIS as well as GIS projects of wide-ranging durations. 13 representatives mentioned that they have practical GIS experience of more than ten years, whereas 6 worked in GIS-related fields for five to eight years. Only 4 had less than four years of experience. In terms of educational background, 3 interviewees held doctoral degrees, and 10 held graduate degrees from a master's program. The rest held bachelor's degrees. More than half of the interviewees (15 representatives) had studied geo-informatics, geography, or geodesy, whereas 2 were IT graduates. The remaining 3 representatives had different educational backgrounds such as forestry, electrical and electronics engineering.

In the second part of the interviews, the representatives were asked to express their views on the NSDI development efforts in Pakistan, and the potential problems facing the country. Most of them acknowledged that the NSDI-Pakistan initiative is quite important and useful not only for the country, but also for their organizations especially for enabling sharing of geospatial data. The NSDI would facilitate to discover and exploit spatial datasets presently held by several public sector organizations. However, some of the interviewees (Int7, Int15, Int16, and Int20) mentioned that the progress made so far is significantly slow because the focus of efforts is on getting more financial resources from the federal government rather than establishing partnerships, especially with the private sector and to give access to the data assets locked by the government organizations. They were of the opinion that the private sector can help to generate revenue by developing various applications and location-based services making use of public sector geospatial data.

The interviewees mentioned the problems related to the smooth implementation of the NSDI in Pakistan based on their perspectives. The problems mentioned are related to data, institution, technical, and human resource issues, as presented in Figure 1.

Five of the representatives mentioned data related issues i.e. lack of digital topographic data, high data cost and over restricted access to geospatial data. An example was the non-availability of data related to administrative boundaries as well as vector data of topographic map sheets on 1:50,000 scale (Int1, Int10, Int12, 
Int18, and Int20). The interviewees recognized the importance of topographic data as the basis for integrating thematic information to carry out spatial planning as well as analysis for supporting evidence-based decision making. Ten of the representatives (Int 9, Int3-6, Int11, Int14, Int 15-17, and Int 19) mentioned institutional issues i.e. lack of coordination mechanism, outdated map/ data policy, stakeholders' passive attitude, absence of data sharing policy, lack of incentives for data sharing organizations, non-existence of partnerships, poor management of the data and budget constraints.

Three representatives (Int2, Int7, and Int13) identified technical issues. They felt that the internet speed in Pakistan is better than India but still no access network and online geoportal has been made available by the government to share and exchange geospatial data. According to (Ookla, 2019), Pakistan ranked at 116th position with an average download speed of $13.55 \mathrm{Mbps}$ whereas India lags behind at 130th place with $10.63 \mathrm{Mbps}$ which supports the above opinion.

Finally, seven representatives (Int1, Int2, Int5, Int7, Int8, Int10, and Int17) mentioned human resource issues, specifically, the insufficient number of government employees who have a formal education of the geospatial domain. The views expressed by the representatives are in line with the recruitment policy of some government organizations such as SoP, which is waiting for approval of the revised recruitment policy since long and consequently is unable to give employment to graduates of GIS and RS fields. The interviewees also mentioned improper staff utilization due to strict transfer and posting policy of the federal government which makes it difficult to achieve progress in the field of geospatial sector especially of public sector organizations (Int1, Int7). 
Figure 1: Problems in NSDI implementation identified by the interviewees






\section{NSDI STAKEHOLDER ANALYSIS}

From the challenges identified in the previous section, institutional issues demand immediate attention. Most of the problems mentioned under institutional issues are directly or indirectly related to stakeholders as "each stakeholder can have an active or passive relationship with any activities or components in an SDI"(Cooper et al., 2019). Therefore, for smooth NSDI implementation aiming at "improved spatial data sharing based on stakeholder engagement requires thorough identification of the actors involved and a good understanding of their motivations and responsibilities" (Schindler et al., 2018).

In order to understand the root causes of the problems identified by the interviewees to implement NSDI in Pakistan, we conducted a stakeholder analysis. This study also analyzes the financial aspect to understand NSDI's budget allocation.

\subsection{Stakeholder Analysis}

The NSDI stakeholder analysis framework follows a three-step process (Reed et al., 2009): identifying stakeholders, categorizing stakeholders, and investigating relationships. For identifying the relevant NSDI stakeholders, documentary evidence, including legal documents, meeting records, and annual reports were collected. The author's involvement in Pakistan's NSDI eased the process of getting access to these documents. In addition, in-depth observation of the geoportals developed by some organizations of the country informed this study. For the categorization of stakeholders, the power-interest grid method was adopted. It is prevalent for classifying stakeholders based on their power to influence and their interest in a project (Ackermann \& Eden, 2011; Reed et al., 2009). The interests and influences of stakeholders were identified during interviews, which were conducted for identification of NSDI implementation problems.

Regardless of the benefits of classifying stakeholders, some limitations of the employed method include a tendency to identify the "usual suspect" due to absence of the stakeholders' direct participation (Reed et al., 2009). To overcome such biases we included four additional features that play important roles in NSDI implementation: geospatial data provision, technological infrastructure, financial resources, and human capacity. Any SDI is an important framework for sharing geospatial data (Barik et al., 2019) and an SDI provides an environment in which users can share and access the geospatial data (Tripathi et al., 2020) though the web (Bucher et al., 2020). Therefore, geospatial data are the focal point of every SDI initiative (Williamson et al., 2003). The delivery of geospatial data is considered as a key variable in assessing NSDIs, especially in developing countries (Eelderink et al., 2008). Access network which is a technological 
infrastructure is essentially required for gaining access to geospatial data, its utilization and harvesting services from SDls (Delgado Fernández et al., 2008). The availability of information is vital for implementation of an NSDI, especially to ascertain the capability of each network node to discover and publish its data as well as for connecting to a national geoportal. Budget or financial resources refer to the sources of funding to implement an SDI, including the budget for data management, institutional arrangements, and necessary software as well as hardware (Delgado Fernández et al., 2008; Masser, 2019). Finally, human resources and their capacity helps to assess the availability of trained and skilled workforce of each stakeholder. Hendriks, Dessers, and van Hootegem (2012) argue that the success of an NSDI is not only depended upon technological components but also skilled human resources are crucial for its effective implementation. Lance, Georgiadou, \& Bregt, (2009) also underscore the important role of trained personnel for smooth implementation of SDIs.

The final step investigates relationships among the stakeholders involved in the implementation of the NSDI. An actor-linkage matrix was defined for listing and describing these interrelations. We choose an actor-linkage matrix because of its ability to assess institutional connections and to quantify the strengths or weaknesses of each linkage in a system (Biggs \& Matsaert, 2004). To determine the relationships among the NSDI stakeholders, three indicators were defined: existence of coordination, occurrence of partnerships, and availability of access network for communication and data sharing. Coordination should be treated as first priority when dealing with SDls for sharing and exchange of geospatial data (Masser, 2019). A lack of coordination is one of the major issues in SDIs developments (Georgiadou et al., 2005; Gittings, 2005; Grus et al., 2007; Masser, 2005a; Nebert, 2004; Williamson et al., 2006). Therefore, any form of coordination formal or informal related to geospatial data among stakeholders facilitates NSDI implementation. The second indicator (partnerships) was used as an instrument to measure stakeholders' formal acceptance to contribute in implementation of the NSDI. The third indicator is the existence of access network, which is used not only for geospatial data sharing among stakeholders but also to discuss NSDI activities, such as meeting plans. Making use of the identified number of interrelations, an actor-linkage graph was developed. The graph portrays the link between the NSDI stakeholders in the local context of Pakistan.

\subsection{Identification of NSDI Stakeholders}

There are various stakeholder groups that are involved in the implementing stage of Pakistan's NSDI. These include public sector organizations (such as federal ministries and their departments, provincial government departments), private companies and academic institutions. Examples of federal departments include SUPARCO, SoP, Geological Survey of Pakistan, National Highway Authority (NDMA) and National Disaster Management Authority (NDMA). Provincial 
departments (such as Urban Policy \& Strategic Planning Sindh) are also involved. Figure 2 shows the cross-sectorial representation of various stakeholders in Pakistan's NSDI.

Figure 2: NSDI stakeholders by type of organization

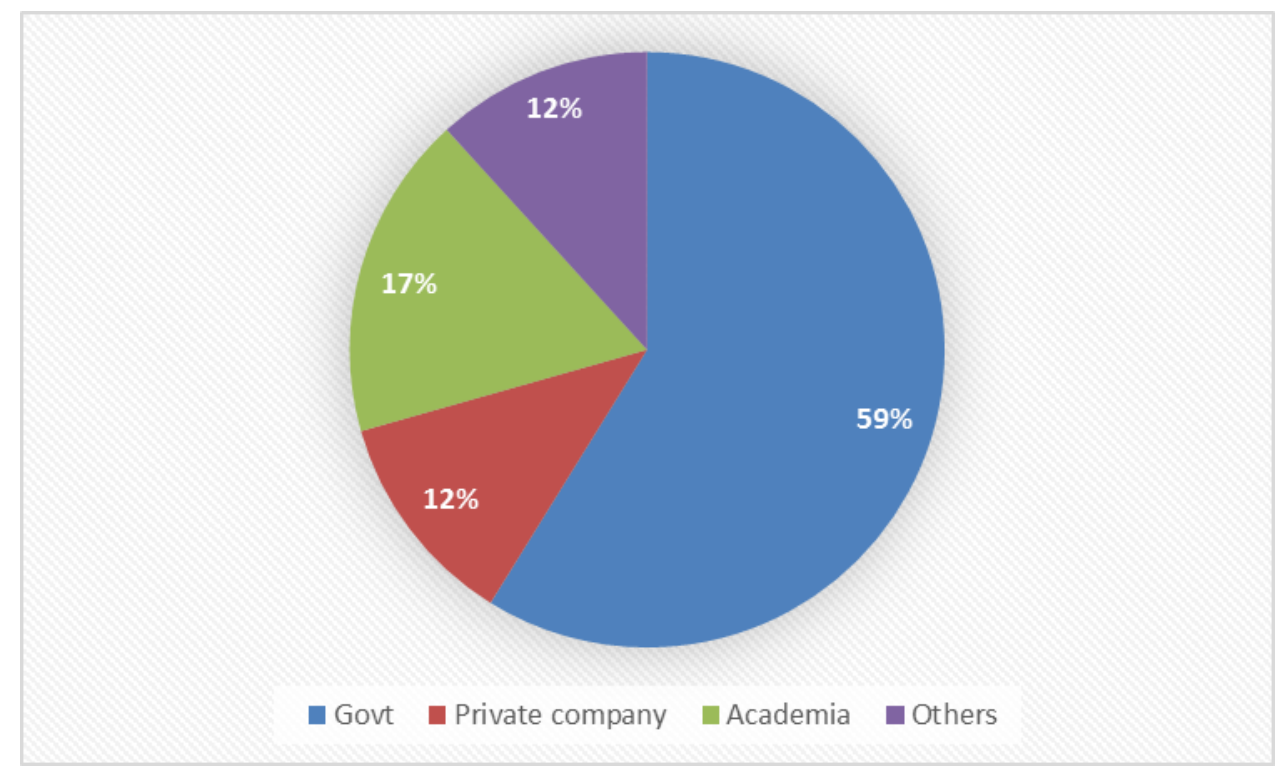

After analyzing the official documents of various organizations, we identified 14 stakeholders involved in Pakistan's NSDI, as presented in the second column of Table 2. 5 stakeholders are from public sector organizations. Each of these organizations is responsible for producing geospatial data in accordance with its mandate given by the government. For instance, the SoP, as the national mapping agency, produces geospatial maps that include topographic layers to be used as base map for integrating thematic information. The provincial governments are responsible for developing data in their administrative areas. According to information available on Pakistan's official website (http://www.pakistan.gov.pk/index.html), the federal government consists of 32 ministries and 74 ministries in the provincial governments. Under these ministries, there is a long list of departments that consume geospatial information for their functioning. 


\subsection{Categorization of NSDI Stakeholders}

All the identified stakeholders certainly have their own interests and power to influence NSDI implementation. Power refers to the stakeholders' capability to arrange their own SDI (Putra et al., 2019). For example, national mapping organization i.e. Survey of Pakistan has an interest in NSDI because SoP has been mandated by the federal government to establish and maintain NSDI for the country with the collaboration of stakeholders (GOP, 2014). SoP is therefore considered more powerful due to Surveying and Mapping Act 2014. Bucher and others (2020) also support this by stating that "[t]he implementation of INSPIRE mainly relies on legally mandated organizations in member states, in charge of providing spatial datasets and services, and in particular the National Mapping Agencies (NMA)". In its capacity, SoP being national mapping agency (NMA) has devised and executing strategy for NSDI implementation but the due human, technical and financial resources have not been provided yet by the federal government however "with a limited amount of resources, it is not possible for an NMA to invest in all technologies" (Bucher et al., 2020) related to NSDI development. In contrast, rest of the stakeholders 7-13 is less powerful as they are not explicitly mandated by the regulation (see Table 2). They are considered as stakeholders and users of NSDI with no responsibility to publish geospatial data in the national geoportal. Based on the results of the conducted interviews and examination of official documents, interest and power of each stakeholder is listed in Table 2.

Generally, there are two types of geospatial data. The first is topographic data that is used as base map and the second type is thematic data such as metrological data that can also be used for several applications as well. For example, metrological data can be used for agriculture as well as for investigating climate change detection. Once both the data are collected and provided in an NSDI, these can be used for many other purposes. In the context of this study, topographic data is hereafter referred to basic geospatial data.

Table 2: Interest and power of NSDI stakeholders in Pakistan

\begin{tabular}{|c|c|c|c|}
\hline No. & Stakeholder & Interest & Power to influence \\
\hline 1. & Survey of Pakistan (SoP) & $\begin{array}{l}\text {-Mandate to implement } \\
\text { NSDI } \\
\text {-Collect basic geospatial } \\
\text { data } \\
\text {-Publish base maps } \\
\text {-Setup national geoportal }\end{array}$ & $\begin{array}{l}\text {-Surveying and } \\
\text { Mapping Act, } 2014 \\
\text {-Functions as a } \\
\text { network node } \\
\text { connector }\end{array}$ \\
\hline
\end{tabular}




\begin{tabular}{|c|c|c|c|}
\hline No. & Stakeholder & Interest & Power to influence \\
\hline 2. & $\begin{array}{l}\text { Ministry of Defence } \\
(\mathrm{MoD})\end{array}$ & $\begin{array}{l}\text { - Utilize geospatial data for } \\
\text { border management }\end{array}$ & $\begin{array}{l}\text {-SoP administratively } \\
\text { works under MoD } \\
\text {-Act as NSDI users }\end{array}$ \\
\hline 3. & $\begin{array}{l}\text { Planning Commission } \\
\text { (PC) }\end{array}$ & $\begin{array}{l}\text { - Develop national public } \\
\text { policies for which } \\
\text { topographic and thematic } \\
\text { datasets are needed }\end{array}$ & $\begin{array}{l}\text {-Funding to public } \\
\text { sector institutions } \\
\text { - Act as NSDI users }\end{array}$ \\
\hline 4. & Federal Government & $\begin{array}{l}\text {-Collect basic geospatial } \\
\text { and thematic data } \\
\text { - Integrate both the datasets }\end{array}$ & $\begin{array}{l}\text {-Provider of basic } \\
\text { geospatial and } \\
\text { thematic data } \\
\text {-Function as network } \\
\text { nodes }\end{array}$ \\
\hline 5. & Provincial Governments & $\begin{array}{l}\text {-Collect basic geospatial } \\
\text { and thematic data } \\
\text {-Integrate data collected by } \\
\text { provincial departments }\end{array}$ & $\begin{array}{l}\text {-Provider of basic } \\
\text { geospatial and } \\
\text { thematic data } \\
\text {-Function as network } \\
\text { nodes }\end{array}$ \\
\hline 6. & District Governments & -Collect thematic data & $\begin{array}{l}\text {-Provider of thematic } \\
\text { data } \\
\text {-Function as network } \\
\text { nodes }\end{array}$ \\
\hline 7. & $\begin{array}{l}\text { Survey and Mapping } \\
\text { Companies }\end{array}$ & $\begin{array}{l}\text {-Collect basic geospatial } \\
\text { and thematic data }\end{array}$ & -Act as NSDI users \\
\hline 8. & Researchers & -Utilize geospatial data & -Act as NSDI users \\
\hline 9. & $\begin{array}{l}\text { Non-Governmental } \\
\text { Organizations }\end{array}$ & $\begin{array}{l}\text {-Collect thematic data } \\
\text { - Seek basic geospatial } \\
\text { data for overlaying collected } \\
\text { thematic information }\end{array}$ & -Act as NSDI users \\
\hline 10. & $\begin{array}{l}\text { GIS Application } \\
\text { Developers }\end{array}$ & $\begin{array}{l}\text {-Collect thematic data } \\
\text {-Develop GIS solutions }\end{array}$ & -Act as NSDI users \\
\hline 11. & GIS Software Providers & $\begin{array}{l}\text {-Provide software for } \\
\text { geospatial data acquisition, } \\
\text { management and } \\
\text { dissemination }\end{array}$ & -Act as NSDI users \\
\hline
\end{tabular}




\begin{tabular}{|c|l|l|l|}
\hline No. & \multicolumn{1}{|c|}{ Stakeholder } & \multicolumn{1}{|c|}{ Interest } & Power to influence \\
\hline 12. & Students & $\begin{array}{l}\text { - Utilize geospatial data } \\
\text {-Access data \& services }\end{array}$ & -Act as NSDI users \\
\hline 13. & Citizens & -Access data \& services & -Act as NSDI users \\
\hline
\end{tabular}

Table 2 was used to develop a power-interest grid of NSDI stakeholders in Pakistan (Figure 3). The grid divides the stakeholders into four categories i.e. quadrants: "Key players", "Context setters", "Subjects", and "Crowd". In the righthand quadrant are the stakeholders who have the most interest in NSDI implementation, but possess varying degrees of power to influence the initiative. The "Key players" are positioned on top of the right-hand side. They are considered to have more influence on the system, whereas: "Subjects" have less. The two lefthand quadrants show the stakeholders with relatively less interest; the "Context setters" may have a high degree of power, while the "Crowd" shows low power and low interest in the system as well. In general, both "Key players" and the "Context setters" are mainly from the public sector. The seven stakeholders with high interest in NSDI, but with less power, are placed in the "Subjects" quadrant. Citizens are considered as "Crowd" as they have relatively low interest and little power to influence the NSDI implementation initiative.

In Figure 3, the four institutions mentioned as "Key players" (blue color) are, SoP (1), federal government departments (4), provincial governments departments (5), district government departments (6). Being custodians of authoritative geospatial data, these stakeholders have a high interest in the data, such as the collection of topographic and thematic data, preparation of topographic and thematic maps, sharing topographic and thematic data, setting up national geoportal. SoP being a lead organization for NSDI development has an additional role as the network nodes connector, and its position is slightly higher than the positions of the other stakeholders in this grid. All "key players" have more power to influence NSDI as per mandates given by the federal government. After "Devolution of Power Plan" by General Pervaiz Musharraf in January 2000 which was implemented in August 2001 (GOP, 2000), several sectors such as agriculture, health, education, revenue, and transport are now a provincial subject in Pakistan. Therefore, provincial governments collect data of their respective sectors, integrate it then share with the federal government when required. 
Figure 3: Power-interest grid of NSDI stakeholders in Pakistan

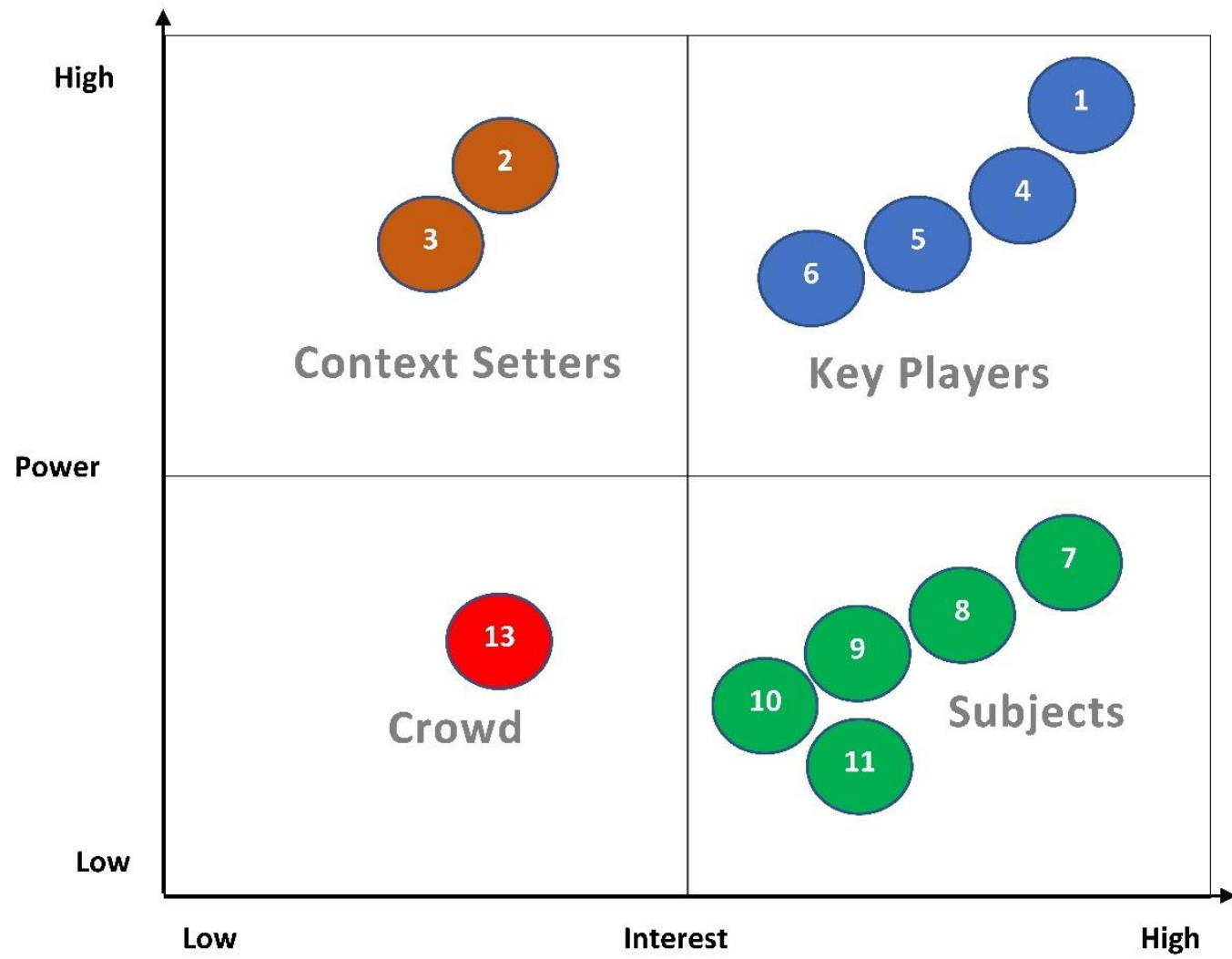

More detailed data such as utilities lies with district governments. They collect the data and handover to the provincial government. However, the federal government is responsible for maintaining data at the national level, and therefore, their position is above the positions of the provincial governments along the vertical hierarchy. Similarly, the provincial government's position is above district governments due to the Devolution of Power Plan by General Pervaiz Musharraf 2000. The "Key players" have strong influences on NSDI implementation since they provide the geospatial data (Putra et al., 2019) and are responsible for setting up web services used by other institutions.

The "Context setters" (in brown) affect NSDI operations but possess low interest. The stakeholders in this group include Ministry of Defence (2), and Planning Commission (3). Ministry of Defence (MoD) consume geospatial data for managing international borders of the country. Planning Commission (PC) of Pakistan has a high power to influence NSDI development due to two reasons. The first reason is, PC is the apex body for national public policy making and NSDI comprises not only technical components but also policies(Lance et al., 2006; Masser, 2005a, 2019). 
The second reason includes, PC provides funds to public sector institutions for their development programmes and it is evident that initial injection of funds is necessary for getting a large-scale geospatial system up (Rajabifard, 2019). Unfortunately, the interest of the context setters is still limited in contributing to NSDI development in the country.

There are six types of stakeholders under the category "Subjects" (in green) that can be divided into private companies, academia, and NGOs. All of them have a strong interest in collecting geospatial data and accessing the data services from the geoportal, particularly students. Private companies have a role in geospatial data acquisition and the development of GIS applications. Most private sector institutions include survey and mapping companies (7), and they get surveying and mapping related projects from local governments usually. With the implementation of Surveying and Mapping Act 2014 (GOP, 2014), the private companies are bound to get registered with the SoP and share one soft copy of their collected data with SoP. Therefore, their position is relatively higher than GIS application developer companies (10) and GIS software providers (11), because private survey and mapping companies contribute to enriching the geospatial database for the NSDI. Researchers (8), NGOs (9), and students (12) are at the same level of interest and power.

The last category is "Crowd" (in red), which comprises citizens (13). They are interested to access the national geoportal for exploring mapping products and looking for topographic map layers such as administrative boundaries.

Although the power-interest grid has advantages (such as characterizing the stakeholders according to their interests and influence), one of the limitations of the power-interest grid is that it cannot identify the correlation between stakeholders' resources. In order to overcome this limitation, the NSDI stakeholder diagram has been created. The diagram is based on the results of the questionnaire surveys from the stakeholders.

Results of the questionnaire show that "Key players" including SoP and $60 \%$ of the other federal government departments have topographic and thematic geospatial data (see Figure 4). Their data can be integrated as SoP has already defined the data standards. The institutions under the category of "Context setters" i.e. Ministry of Defence and Planning Commission get data from SoP and then incorporate their own collected data with it. Therefore, there is no issue of data heterogeneity. Provincial and district governments have most of their geospatial data in GIS formats. Among the "Subjects" stakeholders, private surveying and mapping companies have topographic and thematic geospatial data. GIS application developers, GIS software providers, NGOs, academia, and students do not have authoritative geospatial data. 
Figure 4: Questionnaire results on data provision of the stakeholders

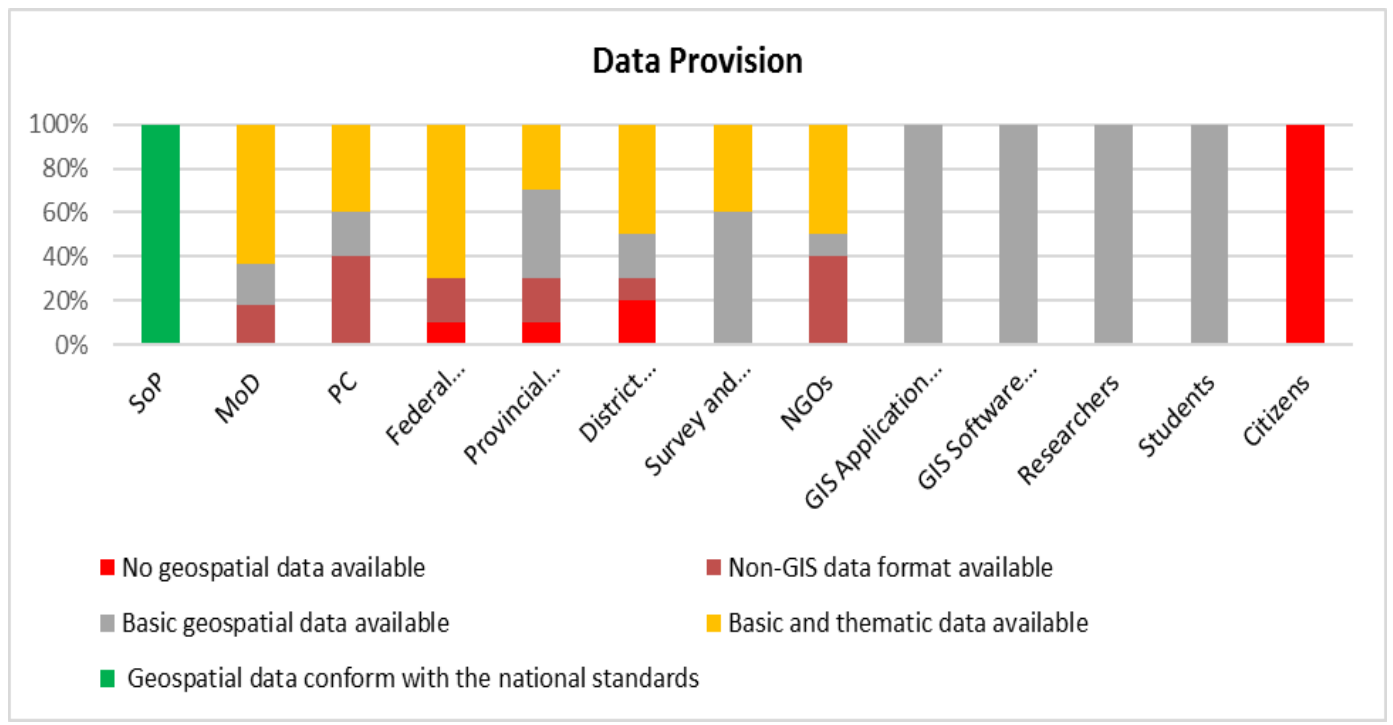

As far as technological infrastructure is concerned, most of the "Key players" are already equipped with the core infrastructure (see Figure 5). SoP, federal government departments, and some provinces have developed geoportals and setup data centers to organize and manage geospatial resources. However, some districts especially in far-flung areas have a shortage of required resources, and only $5 \%$ are capable of making data available through the web. The private sector organizations, geospatial application developers, and providers of GIS software have sufficient technology for publishing geospatial services.

Regarding human capacity, SoP and federal government departments have a sufficient number of skilled personnel (see Figure 6). SoP, being the national mapping organization responsible for geospatial data development, has more than 1300 employees with a background in geography, civil engineering, geoinformatics, computer science, and geodesy. Most federal government departments have more than 10 employees available. Private companies typically have sufficient human resources, too. The insufficient number of GIS personnel exists in most other NSDI stakeholders, including provinces, districts and ministry of defence (MoD) and planning commission (PC). 
Figure 5: Questionnaire results on technological infrastructure

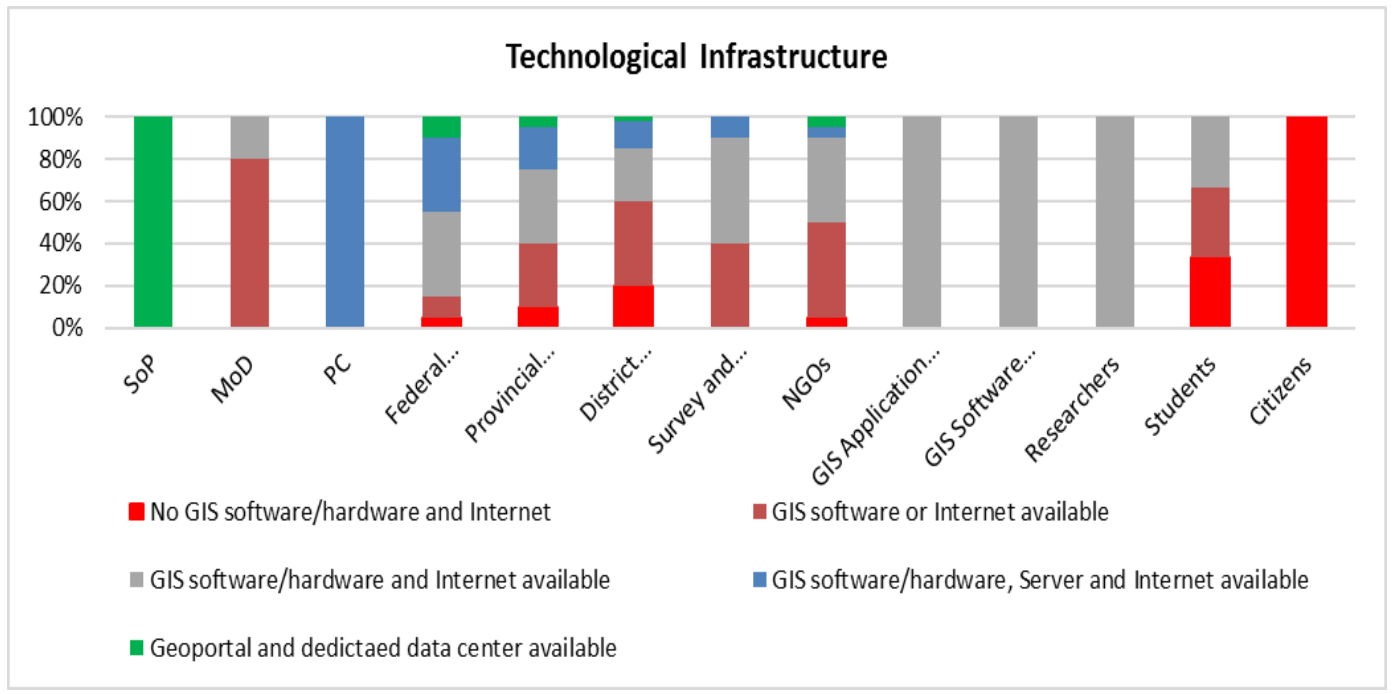

Figure 6: Questionnaire results on human capacity

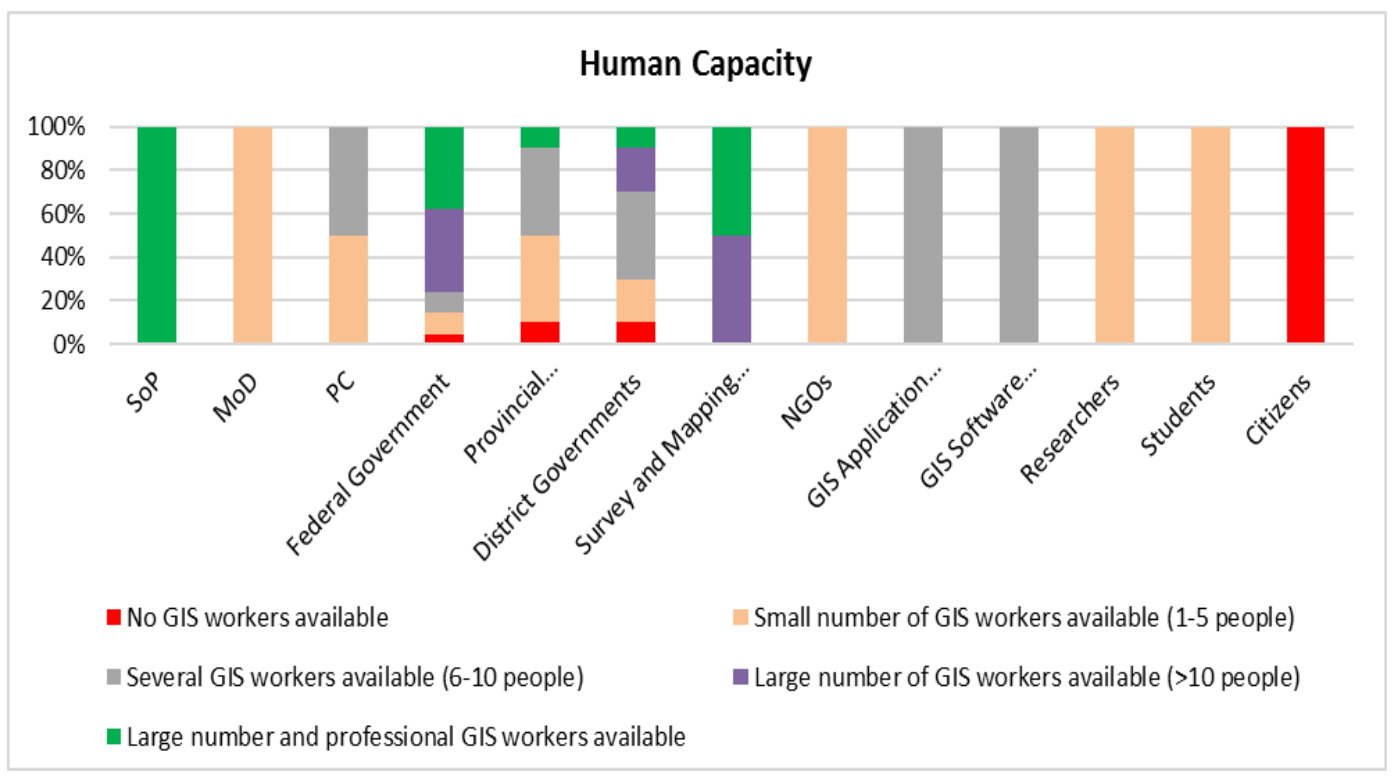

The results of the questionnaire show that financial resources are one of the core issues faced by SoP and other federal departments (see Figure 7). A similar situation exists at the provincial and district level departments. 
Figure 7: Questionnaire results on financial resources

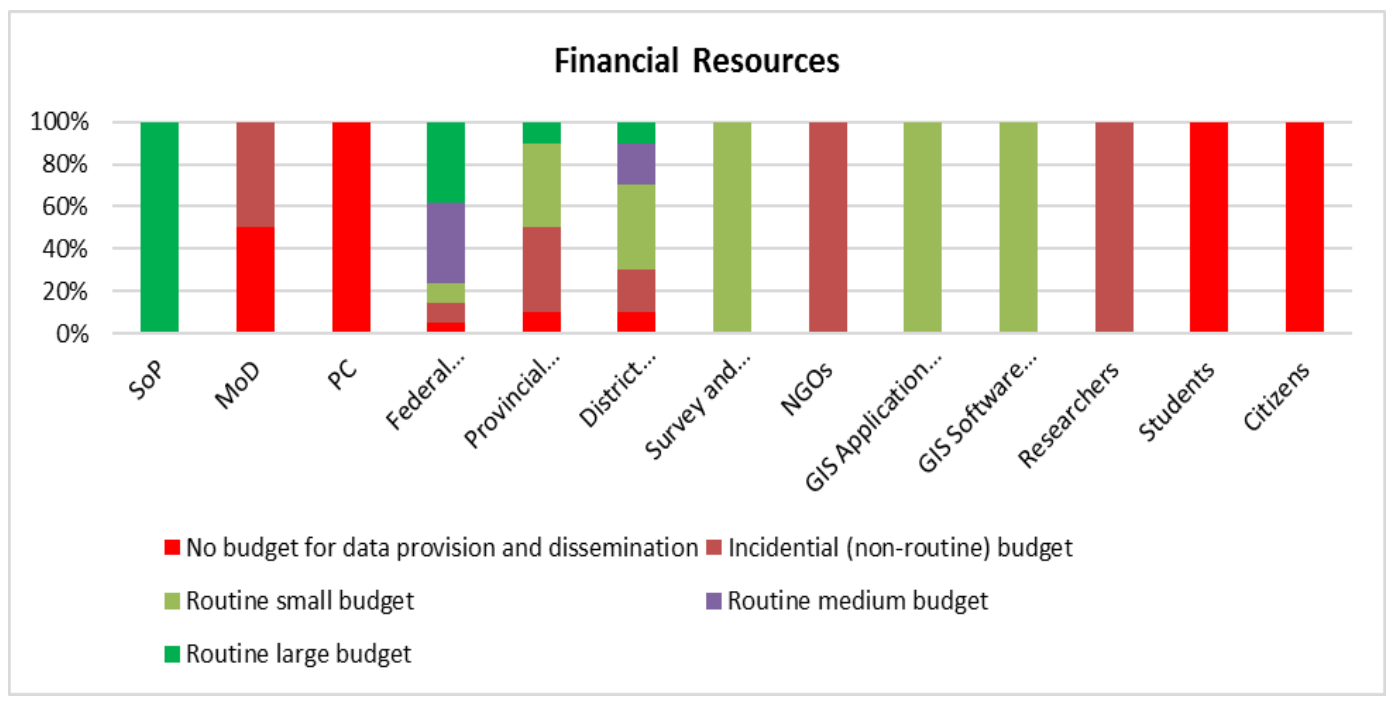

Table 4 has been prepared to show the four NSDI features of stakeholder capabilities, with in-depth indicators presented on a five-point Likert scale. The indicators were extracted from the questionnaire in order to determine each stakeholder's capabilities to implement NSDI in their organization.

Table 4: NSDI determinants and their indicators used in the questionnaire

\begin{tabular}{|l|l|}
\hline \multicolumn{1}{|c|}{ NSDI Determinants } & \multicolumn{1}{|c|}{ Indicators } \\
\hline Geospatial data provision & $\begin{array}{l}1 \text { = No geospatial data available } \\
2 \text { = Non-GIS data format available } \\
3=\text { Basic geospatial data available } \\
4=\text { Basic and thematic data available } \\
5=\text { All of the above, and the data conform with the } \\
\text { national catalogue }\end{array}$ \\
\hline $\begin{array}{l}\text { Technological } \\
\text { Infrastructure }\end{array}$ & $\begin{array}{l}1=\text { No GIS software/hardware and internet } \\
2=\text { GIS software or internet available } \\
3=\text { GIS software/hardware and internet } \\
\text { available }\end{array}$ \\
\hline
\end{tabular}




\begin{tabular}{|c|c|}
\hline NSDI Determinants & Indicators \\
\hline & $\begin{aligned} 4= & \text { GIS software/hardware, GIS server, and } \\
& \text { internet available } \\
5= & \text { All of the above, and the geoportal and } \\
& \text { dedicated data center available }\end{aligned}$ \\
\hline Financial Resources & $\begin{array}{l}1=\text { No budget for data provision and dissemination } \\
2=\text { Incidental (non-routine) budget } \\
3=\text { Small annual budget } \\
4=\text { Medium annual budget } \\
5=\text { Large annual budget }\end{array}$ \\
\hline Human Capacity & $\begin{array}{l}1=\text { No GIS workers available } \\
2=\text { Small number of GIS workers available ( } 1-5 \text { people }) \\
3=\text { Several GIS workers available ( } 6-10 \text { people }) \\
4=\text { Large number of GIS workers available }(>10 \text { people) } \\
5=\text { Large number of professional GIS workers available }\end{array}$ \\
\hline
\end{tabular}

Table 5 shows the average values of the four NSDI features calculated from the questionnaire.

Table 5: Average values of four NSDI features calculated from the questionnaire

\begin{tabular}{|l|l|l|l|l|l|}
\hline No. & \multicolumn{1}{|c|}{ Stakeholder } & $\begin{array}{c}\text { Data } \\
\text { Provision }\end{array}$ & $\begin{array}{l}\text { Technological } \\
\text { Infrastructure }\end{array}$ & $\begin{array}{l}\text { Human } \\
\text { Capacity }\end{array}$ & $\begin{array}{l}\text { Financial } \\
\text { Resource }\end{array}$ \\
\hline 1. & $\begin{array}{l}\text { Survey of Pakistan } \\
(\text { SoP) }\end{array}$ & 5.0 & 5.0 & 5.0 & 5.0 \\
\hline 2. & $\begin{array}{l}\text { Ministry of Defence } \\
(\text { MoD })\end{array}$ & 1.6 & 1.8 & 1.4 & 2.5 \\
\hline 3. & $\begin{array}{l}\text { Planning Commission } \\
(\text { PC })\end{array}$ & 2.0 & 2.0 & 2.0 & 3.0 \\
\hline 4. & Federal Government & 3.6 & 3.7 & 3.5 & 4.0 \\
\hline 5. & $\begin{array}{l}\text { Provincial } \\
\text { Governments }\end{array}$ & 2.2 & 2.5 & 2.1 & 2.6 \\
\hline 6. & District Governments & 3.0 & 1.5 & 1.8 & 1.7 \\
\hline 7. & $\begin{array}{l}\text { Survey and Mapping } \\
\text { Companies }\end{array}$ & 3.0 & 4.0 & 4.0 & 3.0 \\
\hline
\end{tabular}




\begin{tabular}{|l|l|l|l|l|l|}
\hline No. & \multicolumn{1}{|c|}{ Stakeholder } & $\begin{array}{c}\text { Data } \\
\text { Provision }\end{array}$ & $\begin{array}{l}\text { Technological } \\
\text { Infrastructure }\end{array}$ & $\begin{array}{c}\text { Human } \\
\text { Capacity }\end{array}$ & $\begin{array}{l}\text { Financial } \\
\text { Resource }\end{array}$ \\
\hline 8. & Researchers & 3.0 & 3.0 & 3.0 & 2.0 \\
\hline 9. & $\begin{array}{l}\text { Non-Governmental } \\
\text { Organizations }\end{array}$ & 3.0 & 3.0 & 2.0 & 2.5 \\
\hline 10. & $\begin{array}{l}\text { GIS Application } \\
\text { Developers }\end{array}$ & 3.0 & 3.0 & 2.0 & 2.0 \\
\hline 11. & $\begin{array}{l}\text { GIS Software } \\
\text { Providers }\end{array}$ & 3.0 & 3.0 & 2.0 & 2.0 \\
\hline 12. & Students & 3.0 & 3.0 & 2.0 & 2.0 \\
\hline 13. & Citizens & 1.0 & 1.0 & 1.0 & 1.0 \\
\hline
\end{tabular}

Based on the questionnaire results, we calculated the average value of NSDI features using a five-point Likert scale as shown above. Based on calculation results, the NSDI stakeholder diagram was created to visualize the connotation between stakeholders' power and interest with their existing features (Figure 8). The diagram axes represent availability of the stakeholder's current resources. The four quadrants of the power-interest grid are also visible in the figure.

In Figure 8, the "Key players" quadrant shows that only SoP (1) and federal government departments (4) have adequate resources. Whereas the other two players though have strong interest and influence but their problem is the limitations of required resources. For example, provincial government departments (5) are supported by data provision and technological infrastructure but they lack in terms of human capacity. The district government departments (6) are facing shortage of skilled staff, technical resources, and financial support, due to which their contribution towards NSDI is passive.

The "Context setters" quadrant shows that Ministry of Defence (2) has limited NSDI like features, as they only scored 2.0 for most indicators, while Planning Commission (3) has good support in terms of data availability and trained personnel.

The "Subjects" quadrant shows six stakeholders clustered into three groups. The private companies carrying out surveying and mapping activities (7), GIS application developers (10), and GIS software providers (11) share the same capabilities. Researchers (8), NGOs (9), and students (12) face restrictions in labor and financial resources. 
Figure 8: National spatial data infrastructure stakeholder diagram

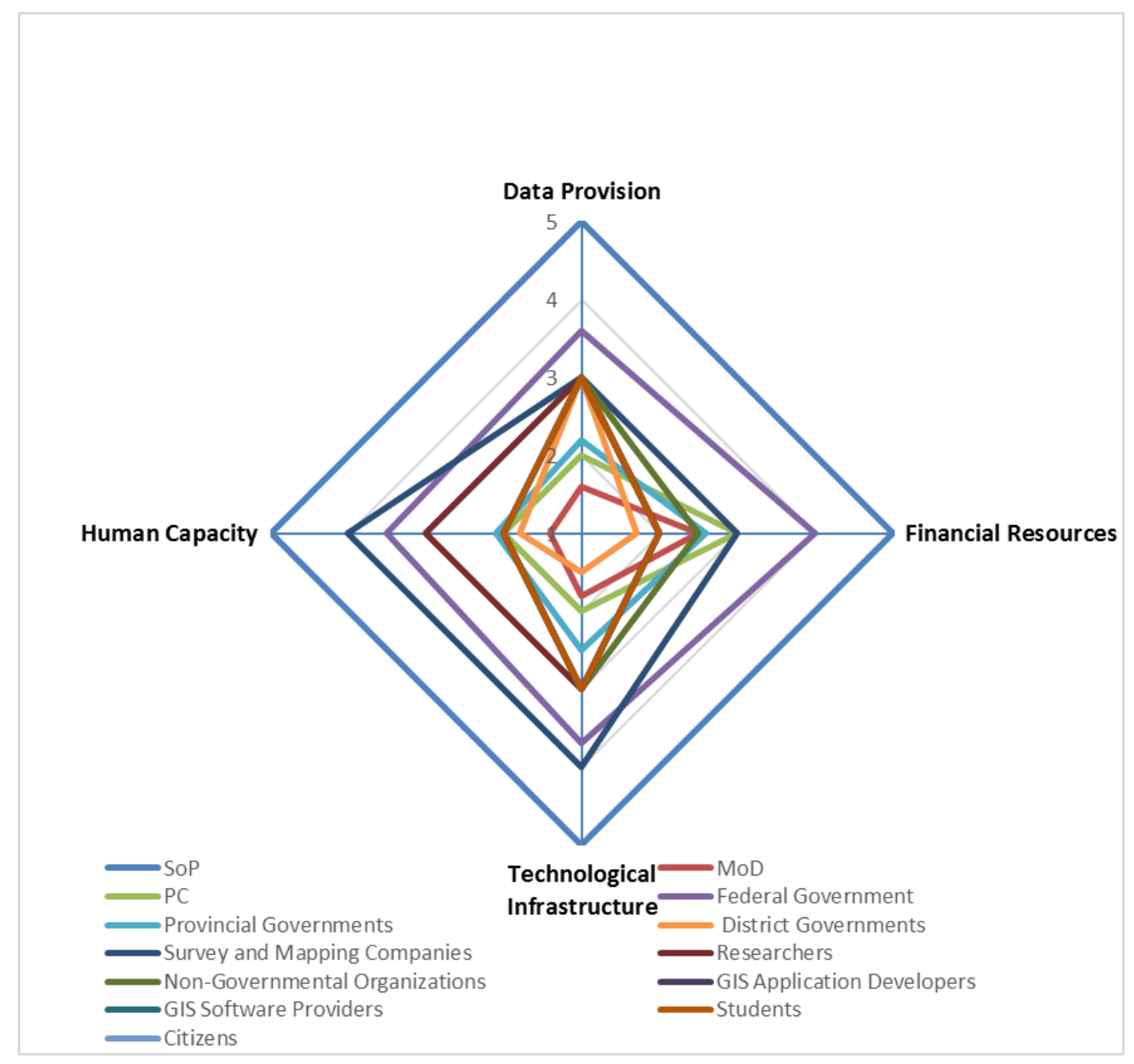

\subsection{Relationships of NSDI Stakeholders}

To explore and quantify the interrelationship among NSDI stakeholders of Pakistan, an action-linkage matrix was created. The number of connections among all the stakeholders are listed in Table 3. The values were determined from official documents such as minutes of meetings, memorandum of understanding (MoU) and post visit reports. It appears that most strong connections are dominated by the SoP followed by private survey companies. Strong relations also exist between federal government departments and SoP. Relatively weak collaboration between federal government departments and the local government in terms of geospatial information usage has been noted. Planning commission maintains strong cooperation with SoP. NGOs, researchers, students, and citizens have relatively weak connections with other stakeholders as shown in Table 6. 
Table 6: Number of connections among NSDI stakeholders in Pakistan

\begin{tabular}{|l|l|l|}
\hline \multicolumn{1}{|c|}{ No. } & \multicolumn{1}{|c|}{ Stakeholder } & \multicolumn{1}{c|}{ Connections } \\
\hline 1. & Survey of Pakistan (SoP) & 5 strong, 3 weak \\
\hline 2. & Ministry of Defence (MoD) & 2 strong, 4 weak \\
\hline 3. & Planning Commission (PC) & 3 strong, 4 weak \\
\hline 4. & Federal Government & 3 strong, 4 weak \\
\hline 5. & Provincial Governments & 1 strong \\
\hline 6. & District Governments & 1 strong, 2 weak \\
\hline 7. & Survey Companies & 4 strong, 1 weak \\
\hline 8. & Researchers & 4 weak \\
\hline 9. & Non-Governmental Organizations & 1 weak \\
\hline 10. & GIS Application Developers & 3 weak \\
\hline 11. & GIS Software Providers & 2 weak \\
\hline 12. & Students & 1 weak \\
\hline 13. & Citizens & 1 weak \\
\hline
\end{tabular}

\section{DISCUSSION}

This study evaluated the NSDI development in Pakistan using stakeholder analysis as the framework for assessment. The NSDI initiative follows a top-down approach as it started with Surveying and Mapping Act 2014(GOP, 2014) by the federal government. That is why most of the key stakeholders belong to the public sector. However, they have dual responsibility, i.e. as data providers and data users. Other characteristics noted are solo organizational efforts by some of the major stakeholders from 2010 to 2014, the non-existence of a formal NSDI coordination agency from the beginning till 2015 and limited skilled human and financial resources as the major constraints.

Indeed, the Surveying and Mapping Act 2014 is a legal formwork for Pakistan's NSDI, but six years after the involvement of all the major stakeholders and their active contribution in NSDI development is still slow. It has been observed that a large number of data providers are not sharing their datasets consequently duplication in the collection of geospatial data is going on. The reasons for nonsharing of geospatial data include issues related to data, institutional, technical and 
human resources issues. As evident from NSDI stakeholder diagram, only SoP and some federal government departments have resources for managing the geospatial data, its sharing and dissemination. However, the interest of most of the federal government departments in the NSDI is not visible. On the other hand, provincial and district governments are still constrained by technological infrastructure and human resources. The interest of Ministry of Defence and Planning Commission is considered low due to budgetary constraints. It is therefore, necessary to analyze this situation so that recommendations can be given to the government for improvement of the situation.

The collaboration of the stakeholders in an SDI environment was examined by prior research from a motivational perspective (Castelein \& Bregt, 2013) and organizational perspective (Van Loenen \& Van Rij, 2008). However, an analysis of their interrelationships was not conducted. To fill this research gap we use an NSDI actor-linkage graph to explore the connection patterns of the "Key players" (government agencies and other stakeholders). SoP, as the coordinating body, has made sincere efforts to establish strong relationships with authoritative data providers, such as federal government departments and some local government departments. However, coordination with the private sector is still limited to the registration of firms carrying out surveying and mapping projects. At present, it appears that not even a single private company is producing geospatial data directly for the NSDI. Such non-existence of private companies producing geospatial data for NSDls has also been noted in some developing countries, including South Africa, Namibia, Ghana (Sinvula et al., 2017). Also, the coordination among data providers and GIS application developers is significantly low. To fulfill the demands of NSDI users, coordination of public and private institutions should improve (Masser, 2005a; 2005b; Hennig, 2011). Thus, the government should consider giving incentives to the private sector.

Without the appropriate funding, NSDIs cannot metalize. The provision of financial resources in the beginning of NSDI developments especially rests with the federal government. It seems close to impossible to implement NSDI with traditional budget allocations, where the budget for NSDI development is mostly allocated to improve the availability and accessibility of geospatial data. Once implemented, NSDI would help to save public money and other resources (Asmat \& Munir, 2012), and users would not have spent much time searching for required data and to obtain it.

The findings of this study help to identify the strengths, weaknesses, opportunities, and threats (SWOT) of the NSDI implementation in Pakistan. Such a SWOT analysis is a helpful tool in matching an organization's resources and defining future strategic directions (Gürel, 2017). 
Strengths:

1. The national geoportal was developed and deployed on Local Area Network (LAN) of SoP in 2013 (de Vries \& Asmat, 2016) as the key product of NSDI development. However, due to financial constraints and lack of interest of the stakeholders the portal was not floated on the Web. Presently, the portal facilitates the sharing and exchange of geospatial information being produced by various directorates of SoP.

2. Surveying and Mapping Act was established in 2014 as the legal foundation of NSDI development. The law has been reinforced by Surveying and Mapping Rules 2015(GOP, 2015). These regulations act as an umbrella for the NSDI initiative in the country.

3. National standards regarding metadata, data production and data quality are already implemented by SoP (Asmat \& Munir, 2012). The same are under implementation by the stakeholders for a long time.

4. Government of Pakistan (GOP) is well aware of the benefits associated with geospatial information. On 11th March 2020, GOP with the help of World Bank has launched Data 4 Pakistan portal (http://data4pakistan.com/) which is the first initiative of its kind in Pakistan providing free access to a spatial interactive portal that has poverty estimates for every district in Pakistan. Similarly, two years ago, on 22nd May 2018, GOP approved Digital Pakistan Policy (GOP, 2018) which includes revamping Geographical Information Systems (GIS) for Pakistan to monitor the environment and plan sustainable agriculture. The Egovernment program launched in 2003 also included GIS for Agriculture, Natural Resources \& Urban Property of Pakistan, Mapping \& Database of National Cartographic data (Asmat, 2008). Therefore, geospatial information has been regarded since long as a valuable resource for national planning, socio-economic development, and prosperity of the country.

\section{Weaknesses:}

1. The participation of institutions in the NSDI network is low. According to the stakeholder analysis, SoP and some federal government departments are active participants. Provincial and district governments are impeded due to lack of available resources, whereas the private sector is hampered by their limited role in NSDI implementation.

2. There are insufficient human resources with ICT skills (GOP, 2018) and in the SDI related field(de Vries \& Asmat, 2016). Transfer/posting policy especially of trained manpower also one of the weaknesses that hampers the smooth implementation of the NSDI as mentioned by the departmental representatives during interviews. Also employing non-GIS personnel on spatial assignments creates problems. 
3. Available large-scale basic geospatial data are incomplete. The available data are mostly in medium-scale $(1: 50,000)$ due to which provincial and district governments face difficulties in conducting urban planning and land management.

4. Though the legal foundations have been established, an unanimously accepted NSDI implementation strategy has not yet been prepared. The strategy is important as it provides visions, action plans, and time management for the implementation. The absence of this strategy may cause delay in the implementation of the initiative.

\section{Opportunities:}

1. Presently, data4pakistan portal lacks multiple datasets, such as environment, irrigation network and cadaster. The data that has been used is highly aggregated whereas for implementing development plans, detailed geospatial information is needed. Therefore, it is an opportunity to leverage NSDI data and services.

2. Due to easy access to the Internet, people are now more aware of geospatial information in almost every society. They are using geospatialrelated applications to order online transportation (e.g., Careem) or food delivery service (e.g., Food panda). These applications require readily available geo- information as a service. Therefore, it is an opportunity to leverage NSDI data and services.

3. As stated in Digital Pakistan Policy (GOP, 2018), the development of agriculture sector is on the political agenda. GIS for agriculture would require multiple datasets such as integrated water resources, irrigation network, soil and metrological data. These datasets once placed in NSDI would serve the purpose mentioned by GOP but can be used for several other sectors.

\section{Threats:}

1. Many stakeholders consider the Internet and ICT infrastructures to be a barrier rather than opportunity due to the reliability of the internet for publishing geospatial data and communicating with the national geoportal.

2. Misuse of data, fear of losing ownership, and lack of incentives for sharing data were identified as the major concerns by the interviewees that impede sharing of geospatial data among NSDI institutions.

3. Lack of dedicated funding for implementing NSDI exists in almost all government departments. Without dedicated and smooth funding, NSDI implementation would fail to achieve its overriding objective i.e. sharing of geospatial data. Therefore, GOP should inject money to implement the initiative as financial support from the private sector is unreliable. 


\section{CONCLUSIONS AND RECOMMENDATIONS}

This study identified the evolution of NSDI in Pakistan since 2010. The initiative was developed over four periods between 2010 and 2020 - influenced by the technological changes in geospatial data management. Despite support from leaders and the existence of legal instruments for NSDI development, stakeholders still face considerable challenges. The major obstacles are related to limitations in technical resources, financial support, and skilled workforce, which result in low participation in the NSDI network. Lack of partnerships as well as incentives for geospatial data sharing organizations hamper implementation of NSDI in the country, too.

An NSDI stakeholder diagram and an NSDI actor-linkage graph were created to explore the interrelationships of the stakeholders. These tools were found helpful in evaluating NSDI development in Pakistan. Application of the NSDI stakeholder diagram helped to distinguish and categorize the stakeholders accord to their interests, influence, and capacity. These tools can be valuable additions to the current framework for NSDI assessment.

This study suggests several guidelines as the way forward for the smooth implementation of NSDI based on the presented SWOT analysis:

- First, the recently formed NSDI coordinating committee should prepare a comprehensive document defining role of every stakeholder involved in the implementation of the NSDI initiative. This would help in tackling institutional, technical and resource limitation problems presently being faced by the stakeholders. The top-down approach will work well as it can help to get a commitment from top-level executives that can be instrumental in minimizing inter-agency conflicts, especially among the public sector organizations and improving interactions among the network nodes.

- Second, it is important to describe the NSDI objectives, deliverables, and action plans in a detailed manner. The detailed guidelines need to be prepared and shared among all the stakeholders to manage and share geospatial data in the distributed environment. An NSDI implementation strategy with key performance indicators (KPIs) including design elements of the NSDI is required for guidance of the stakeholders. Monitoring and Evaluation (M\&E) is essential for the success of every project. Therefore, a M\&E committee is also required to ensure promised outcomes of the NSDI.

- Finally, NSDIs cannot be implemented without continuous support from all levels of governments. Present government has taken many key initiatives such as the launch of data4pakistan portal(http://data4pakistan.com/), Digital 
Pakistan initiative and Digital Pakistan Policy 2018(GOP, 2018). Geospatial information will serve as fundamental framework data to achieve objectives of the initiatives recently taken by the GOP. Therefore, GOP should take ownership of the NSDI development as it has been observed that the due role of GOP is less visible. It is also necessary to have a platform such as Planning Commission that can stimulate active interactions among stakeholders of the NSDI.

\section{REFERENCES}

Ackermann, F., \& Eden, C. (2011). Strategic Management of Stakeholders: Theory and Practice. Long Range Planning. https://doi.org/10.1016/j.Irp.2010.08.001

Almirall, P. G., \& Bergadà, M. M. (2008). The socio-economic impact of the spatial data infrastructure of Catalonia. EUR 23300 EN. Luxembourg (Luxembourg): European Commission; 2008. JRC44168.

Asmat, A. (2008). Potential of Public Private Partnership for NSDI implementation in Pakistan. Masters Thesis, University of Twente,Enschede, The Netherlands.

Asmat, A. (2009). What does Spatial Data Infrastructure mean to Pakistan? GSDI 11 World Conference - Spatial Data Infrastructure Convergence: Building SDI Bridges to Address Global Challenges, Rotterdam The Netherlands 15-19 June 2009.

Asmat, A. (2010a). How Does NSDI Development Fit into Pakistan's EGovernment Programme? GSDI 12 World Conference-Realising Spatially Enabled Societies.

Asmat, A. (2010b). The role of remote sensing in fighting against terrorism- A case of Pakistan. International Archives of the Photogrammetry, Remote Sensing and Spatial Information Sciences - ISPRS Archives.

Asmat, A., \& Munir, A. (2012). Is SDI Development, Waste of Time and Money for Pakistan?

Asmat, A., \& Munir, A. (2013). Geospatial Data Sharing in Pakistan: Possibilities and Problems. Spatial Enablement in Support of Economic Development and Poverty Reduction. http://www.gsdi.org/gsdiconf/gsdi14/papers/69.pdf

Ayanlade, A., Orimoogunje, I. O. O., \& Borisade, P. B. (2008). Geospatial data infrastructure for sustainable development in sub-saharan countries. International Journal of Digital Earth, 1(3), 247-258. https://doi.org/10.1080/17538940802149940

Barik, R. K., Dubey, H., Mankodiya, K., Sasane, S. A., \& Misra, C. (2019). GeoFog4Health: a fog-based SDI framework for geospatial health big data 
analysis. Journal of Ambient Intelligence and Humanized Computing, 10(2), 551-567. https://doi.org/10.1007/s12652-018-0702-x

Biggs, S., \& Matsaert, H. (2004). Strengthening Poverty Reduction Programmes Using an Actor-Oriented Approach: Examples from Natural Resources Innovation Systems. Agricultural Research and Extention Network.

Bucher, B., Tiainen, E., Von Brasch, T. E., Janssen, P., Kotzinos, D., Čeh, M., Rijsdijk, M., Folmer, E., Van Damme, M. D., \& Zhral, M. (2020). Conciliating perspectives from mapping agencies and web of data on successful European SDls: Toward a European geographic knowledge graph. ISPRS International Journal of Geo-Information. https://doi.org/10.3390/ijgi9020062

Čada, V., \& Janečka, K. (2016). The strategy for the development of the infrastructure for spatial information in the Czech Republic. ISPRS International Journal of Geo-Information. https://doi.org/10.3390/ijgi5030033

Campagna, M., \& Craglia, M. (2012). The socioeconomic impact of the spatial data infrastructure of Lombardy. Environment and Planning B: Planning and Design. https://doi.org/10.1068/b38006

Castelein, W., \& Bregt, A. (2013). The Role of Collaboration in Spatial Data Infrastructures Making Sense View project $\mathrm{PhD}$ thesis of Giulia Salvini "REDD+ and climate smart agriculture in landscapes. From National design to local implementation" View project. URISA Journal.

Cooper, A. K., Coetzee, S., Rapant, P., Iwaniak, A., Hjelmager, J., Moellering, H., Huet, M., \& Sinvula, K. (2019). Expanding the ICA model of stakeholders in a spatial data in-frastructure (SDI). 15-20. https://doi.org/10.5194/ica-abs-1-492019

Crompvoets, J., de Bree, F., van Oort, P., Bregt, A., Wachowicz, M., Rajabifard, A., \& Williamson, I. (2007). Worldwide impact assessment of spatial data clearinghouses. URISA Journal.

Crompvoets, J., Leuven, K. U., \& Bregt, A. (2007). National spatial data clearinghouses, 2000-2005. In H. Onsrud (Ed.), In Research and Theory in Advancing Spatial Data Infrastructure. ESRI press Redlands, CA.

De Man, W. H. E. (2006). Understanding SDI; complexity and institutionalization. International Journal of Geographical Information Science, 20(3), 329-343. https://doi.org/10.1080/13658810500399688

de Vries, W. T., \& Asmat, A. (2016). The Theory versus the Reality of Alignment between EGov and SDI in Pakistan. In Spatial Enablement in a Smart World (pp. 111-131). GSDI Association Press.

Delgado Fernández, T., Fernández, M. D., \& Andrade, R. E. (2008). The Spatial Data Infrastructure Readiness model and its worldwide application. A Multi- 
View Framework to Assess SDIs, 117-134.

Diaz, L., Remke, A., Kauppinen, T., Degbelo, A., Foerster, T., Stasch, C., Rieke, M., Schaeffer, B., Baranski, B., Bröring, A., \& Wytzisk, A. (2012). Future SDI - Impulses from Geoinformatics research and IT trends. International Journal of Spatial Data Infrastructures Research. https://doi.org/10.2902/17250463.2012.07.art18

Eelderink, L., Crompvoets, J., \& de Man, E. (2008). Towards key variables to assess National Spatial Data Infrastructures (NSDIs) in developing countries. A Multi-View Framework to Assess SDIs, October 2015, 307-325.

Fernández, T. ., \& Crompvoets, J. (2008). Evaluating Spatial Data Infrastructures in the Caribbean for sustainable development. GSDI-10 Conference, Small Island Perspectives on Global Challenges: The Role of Spatial Data in Supporting a Sustainable Future, 313.

Georgiadou, Y., Puri, S. k., \& Sahay, S. (2005a). The Rainbow Metaphor: Spatial Data Infrastructure Organization and Implementation in India. International Studies of Management \& Organization, 35(4), 48-70. https://doi.org/10.1080/00208825.2005.11043738

Georgiadou, Y., Puri, S. K., \& Sahay, S. (2005b). Towards a potential research agenda to guide the implementation of Spatial Data Infrastructures - A case study from India. International Journal of Geographical Information Science, 19(10), 1113-1130. https://doi.org/10.1080/13658810500286950

Gittings, B. M. (2005). Geospatial Data Infrastructure-Concepts, Cases, and Good Practice. The Photogrammetric Record. https://doi.org/10.1111/j.1477$\underline{9730.2005 .003172 . x}$

GOP. (2000). Local Government Plan. National Assembly of Pakistan. http://www.na.gov.pk

GOP. (2014). Surveying and Mapping Act 2014. National Assembly of Pakistan. http://www.na.gov.pk/uploads/documents/1397721138 588.pdf

GOP. (2015). Surveying and Mapping Rules 2015. National Assembly of Pakistan. http://sop.gov.pk/images/downloads/surveying and mapping rules 2015.p df

GOP. (2018). Digital Pakistan Policy (p. 24). Ministry of Information and Broadcasting,Government of

Pakistan. http://moib.gov.pk/Downloads/Policy/DIGITAL PAKISTAN POLICY(22-052018).pdf

Grus, L., Crompvoets, J., \& Bregt, A. K. (2007). Multi-view SDI Assessment Framework. International Journal of Spatial Data Infrastructures Research, 2(2), 33-53. 
Gürel, E. (2017). Swot Analysis: A Theoretical Review. Journal of International Social Research. https://doi.org/10.17719/iisr.2017.1832

Harvey, F., Iwaniak, A., Coetzee, S., \& Cooper, A. K. (2012). SDI Past, Present and Future: A Review and Status Assessment. In Spatially Enabling Government, Industry and Citizens: Research and Development Perspectives.

Hendriks, P. H. J., Dessers, E., \& van Hootegem, G. (2012). Reconsidering the definition of a spatial data infrastructure. International Journal of Geographical Information Science, 26(8), 1479-1494. https://doi.org/10.1080/13658816.2011.639301

Lance, K. T., Georgiadou, Y., \& Bregt, A. K. (2009). Cross-agency coordination in the shadow of hierarchy: "Jjoining up" government geospatial information systems. International Journal of Geographical Information Science. https://doi.org/10.1080/13658810801909615

Lance, Kate Trinka, Georgiadou, Y., \& Bregt, A. (2006). Understanding how and why practitioners evaluate SDI performance. In International Journal of Spatial Data Infrastructures Research (Vol. 1). https://ijsdir.sadl.kuleuven.be/index.php/ijsdir/article/view/19

Maguire, D. J., \& Longley, P. A. (2005). The emergence of geoportals and their role in spatial data infrastructures. Computers, Environment and Urban Systems. https://doi.org/10.1016/j.compenvurbsys.2004.05.012

Masser, I. (1999). All shapes and sizes: The first generation of national spatial data infrastructures. International Journal of Geographical Information Science. https://doi.org/10.1080/136588199241463

Masser, I. (2005a). GIS worlds: creating spatial data infrastructures (Vol. 338). ESRI Press.

Masser, I. (2005b). The Future of Spatial Data Infrastructures. In ISPRS Workshop on Service and Application of Spatial Data Infrastructure. www.EIS-Africa.org

Masser, I. (2019). From Geographic information systems to Spatial data infrastructures : a global perspective (1st ed.).

Nebert. (2004). Developing Spatial Data Infrastructures: The SDI Cookbook v. 2.0.

Nikolina Mijić, S., \& Šestić, M. (2018). Future development of NSDI based on the European INSPIRE Directive-A case study of a Bosnian and Herzegovinian geoportal. International Journal of Spatial Data Infrastructures Research, 13, 315-338. https://doi.org/10.2902/1725-0463.2018.13.art19

Ookla. (2019). Speed test Global index for January. https://www.newindianexpress.com/world/2019/sep/11/pakistan-leavesindia-behind-in-mobile-internet-speed-2032226.html 
Panagiotis, T., \& Maria, P. (2013). Greek National Spatial Data Infrastructure: Attempts towards Design and Implementation $\square$. International Journal of Spatial Data Infrastructures Research, 8, 21-42. https://doi.org/10.2902/1725-0463.2013.08.art2

Putra, T. Y. D., Sekimoto, Y., \& Shibasaki, R. (2019). Toward the evolution of national spatial data infrastructure development in Indonesia. ISPRS International Journal of Geo-Information, 8(6). https://doi.org/10.3390/ijgi8060263

Rajabifard, A. (2019). Sustainable Development Goals Connectivity Dilemma. In Sustainable Development Goals Connectivity Dilemma. CRC Press. https://doi.org/10.1201/9780429290626

Reed, M. S., Graves, A., Dandy, N., Posthumus, H., Hubacek, K., Morris, J., Prell, C., Quinn, C. H., \& Stringer, L. C. (2009). Who's in and why? A typology of stakeholder analysis methods for natural resource management. Journal of Environmental Management, 90(5), 1933-1949. https://doi.org/10.1016/.j.jenvman.2009.01.001

Richter, C., Miscione, G., \& Georgiadou, Y. (2010). Conceptualizing people in SDI literature: Implications for SDI research and development. International Journal of Spatial Data Infrastructures Research.

S Hennig, M. B. (2011). User-centric SDI: Addressing Users Requirements in Third- Generation SDI. The Example of Nature-SDIplus. Geoforum Perspektiv, 10(20). https://doi.org/10.5278/ojs.persk.v10i20.448

Schindler, M., Dionisio, R., \& Kingham, S. (2018). A multi-level perspective on a spatial data ecosystem: needs and challenges among urban planning stakeholders in New Zealand $\square$. International Journal of Spatial Data Infrastructures Research, 13, 223-252. https://doi.org/10.2902/17250463.2018.13.art15

Sinvula, K. M., Coetzee, S., Cooper, A. K., Owusu-Banahene, W., Nangolo, E., Rautenbach, V., \& Hipondoka, M. (2017). A comparative analysis of stakeholder roles in the spatial data infrastructures of South Africa, Namibia and Ghana $\square$. International Journal of Spatial Data Infrastructures Research, 12, 1. https://doi.org/10.2902/1725-0463.2017.12.art1

Tripathi, A. K., Agrawal, S., \& Gupta, R. D. (2020). A Conceptual Framework of Public Health SDI. In Lecture Notes in Civil Engineering (Vol. 33, pp. 479487). Springer. https://doi.org/10.1007/978-981-13-7067-0 37

Van Loenen, B., \& Van Rij, E. (2008). Assessment of Spatial Data Infrastructures From an Organisational Perspective. In A Multi-view Framework to Assess Spatial Data Infrastructures (pp. 173-192). artment of Geomatics, The University of Melbourne. http://www.csdila.unimelb.edu.au/publication/multi- 
view-framework/Chapter 9.pdf

Williamson, I., Rajabifard, A., \& Binns, A. (2006). Challenges and Issues for SDI Development. International Journal of Spatial Data Infrastructures Research, 1, 24-35.

Williamson, Rajabifard, A., \& Feeney, M. (2003). Developing spatial data from concept to reality. https://content.taylorfrancis.com/books/download?dac=C2004-0-13648$\underline{\text { X\&isbn }=9781134414796 \& \text { format }=\text { googlePreviewPdf }}$ 